\title{
Review
}

\section{The Review on the European and the United States Healthcare Systems}

\author{
Andrew S. Targowski, PhD* \\ Western Michigan University, Kalamazoo, MI 4908, USA \\ "Corresponding author \\ Andrew S.Targowski, PhD \\ Professor Emeritus, International Society for the Comparative Study of Civilizations President (2007-2013), Western Michigan University, Kalamazoo, MI 4908, \\ USA; E-mail: Andrew.targowski@wmich.edu
}

\section{Article information}

Received: July Ist, 2020; Revised: July 2I ${ }^{\text {st }}, 2020$; Accepted:August II ${ }^{\text {th }}, 2020$; Published: August 28 ${ }^{\text {th }}$, 2020

\section{Cite this article}

Targowski AS. The Review of the European and the United States healthcare systems. Public Health Open J. 2020; 5(3): 58-67. doi: 10.17/40/PHOJ-5-I49

\section{| ABSTRACT}

The paper investigates the main ideas and solutions of healthcare systems in leading countries such as Switzerland, the Netherlands, Denmark, Sweden, Austria, France based on the international ranking indexes such as the United Nations Human Development Index, Genuine Progress Indicator (GPI), Blumberg's Global Health Index, World Health Organization (WHO), The Healthcare Access \& Quality Index (HAQ), the European Health Consumer Index (EHCI). In conclusion, the health of society depends to a great extent on lifestyle and climate, where such countries as Spain and Italy have fewer sick people, and it results in a lower burden on healthcare. Unites States of America healthcare must compensate for lifestyle defects with intensive treatment and expensive medicines. This costs money and, what is worse, it doesn't bring any noticeable progress. As evidenced by the dramas caused by the 2020 pandemic.

\section{Keywords}

Healthy life; Healthy lifestyle; American healthcare; Healthcare indexes.

\section{INTRODUCTION}

A bout 1000-years-ago, the average life expectancy of people

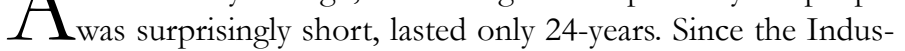
trial Revolution $(1820+)$, it increased to 36-years after the Second World War, in 1950 ${ }^{\text {th }}$-reached 66-years, and in 1999 it covers 78-years for developed countries. Such a promising extension of people's lives because it was up to three times thanks to the development of medicine, and thus people are living longer and longer. Knowledge, including medical, proved to be an excellent engine for the development of civilization. It is worth noting that the development gap between the leader, which is the United States and Africa, is currently 20 to $1 .^{1}$ And in 1000 developed countries (belonging to Western civilization) were more unfortunate than countries in Asia and Africa! Nowadays, the situation reversed people live longer in Western civilization but perhaps reached their potential. Due to the unhealthy lifestyle, the next generations may live shorter.

\section{THE PURPOSE OF HUMAN LIFE}

The present man not only dreams but demands that the healthcare service take care of his/her health, to be able to achieve his ambitious goals in his long life. The condition for this is above all good health, without affecting the fact that there is no raison d'être. Aristotle 2350-years-ago claimed that people are stupid because they do not know the purpose of life, so you can not make wise decisions in everyday life. Well, then man lived under 24-years, and his goal was to survive until tomorrow so as not to be killed, starve or be taken a prisoner. Now people can live up to 100 -years and worry what to do in such a long life.

Before you develop a healthcare information strategy, you need to think about what it should be, make it computerized in favorable conditions. Therefore, first, you need to think about the idea of good health services that are worth informing and then deal with strategic solutions for its computerization. The human life purpose model is shown in Figure 1, which indicates that to live a long and happy life, people should know their live purposes, which change along with their experience.

According to the Model of the Hierarchy of Life Purposes (MLP), living a healthy life, after securing life in peace, is the 


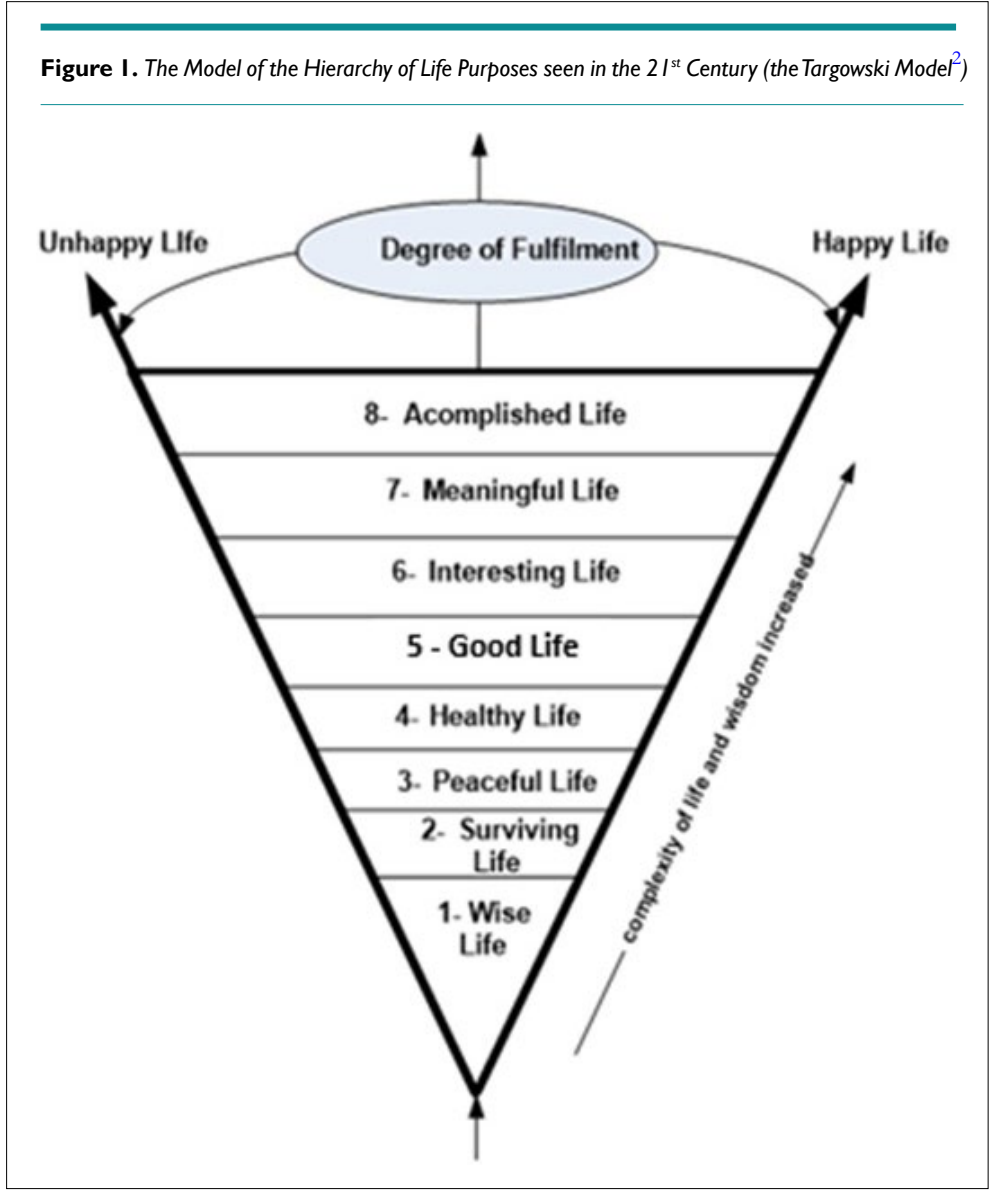

basis for achieving several advanced life goals. It is evident that to achieve these goals, a man should be wise. Hence the questions about our wisdom of social life:

- Do people set proper operational and development priorities for their communities?

- What is the position of the health service among these priorities?

Caring for patients' health and prevention should be at the top of every priority list of the state and its society.

\section{PUBLIC HEALTHCARE INDICATORS}

The assessment of people's quality of life is dominated by economic indicators, such as Gross Domestic Product (GDP), Consumer Confidence Index, and several others, etc. They are calculated and published daily (e.g., GDP), weekly, monthly, quarterly, or annually. There are several indicators regarding health care, and they are updated and published in cycles of several months (child abuse), annual (life expectancy), and even every 2-3-years (infant mortality, number of adolescent suicides). Only some countries calculate and publish concentrated assessments of the health quality of their society. Without this type of comprehensive public health assessment, the state of the economy is misleading. Today, unfortunately, there are countries where the economy is developing well, but soci- ety's health is deteriorating. Can politicians be proud of their policy in such a situation?

In the United States, the Fordham Institute of the University Index of Social Health (FISH) published by Fordham Institute Social Health is based on 16 indicators ${ }^{3}$ :

1. Infant mortality

2. Child abuse

3. Poverty among children

4. Teen suicide

5. Drug abuse

6. Early school leaving

7. Average weekly earnings

8. Unemployment

9. Scope of health insurance

10. The poverty of older people

11. Health insurance for the elderly

12. Deaths on the highway due to alcohol

13. Murders

14. Distribution of food stamps

15. Apartment

16. Inequality of income.

Since 1973, the FISH index has fallen with the growth of US GDP. In Canada, the FISH index has remained stable since 
1985. together with GDP growth. So economic success is obtained at the expense of human health. Is it worth it?

Another social health index used by the United States is.

\section{Genuine Progress Indicator}

Genuine Progress Indicator (GPI) which aims to change the dominant definition of progress from economic growth to a sense of people's quality of life. GPI attributes value to life-sustaining functions of households, communities, and the environment so that their destruction and replacement with substitutes are no longer visible as growth and profit. GPIs include ${ }^{4}$ :

1. Unpaid work (housework, parenting, and care)

2. Crime

3. Family break up

4. Work at home

5. Volunteer work

6. Division of income

7. Depletion of resources

8. Pollution

9. Expenses for defense

10. Long-term environmental damage (wetlands, ozone, arable fields),

11. Changes in free time

12. The durability of durable goods and public infrastructure

13. Dependence on foreign assets

14. Services (highways, streets)

15. Loss of free time (for dedicating the community, yourself, hobby, relaxation, spending time with family)

16. Costs of car accidents

17. Insufficient employment costs

18. Costs of noise pollution and household pollution (disease syndrome)

Quality of life has deteriorated at a faster pace since 1970GPI has decreased along with the increase in US GDP. In Canada, when the GDP increased, the GPI did not rise but remained stable.

The GPI index puts emphasis on the economic factors which supposedly define "genuine progress." However, the health-oriented criteria are not included in it. The United Nations Human Development Index (UNHDI) includes the health-driven factors together with the economic ones.

\section{The United Nations Human Development Index}

The United Nations Human Development Index is based on the assumption that growth in economic development does not necessarily mean human development or an increase in prosperity. This indicator measures the impact of growth (or lack thereof) on people and not on the economy. The United Nations Development Program developed this index and displayed in Table 1. The rating can range from 1,000 (highest rating) to 0.000 (lowest score).
The topscore is above 0.890 . Canada took first place in the last four-years (0.960), the USA (0.942), which ranks fourth is slightly behind Norway and France (1997). UNHDI measures health, education, and income according to the following indicators ${ }^{5}$ :

1. Expected life expectancy

2. Access to education and literacy for adults

3. Years of learning

4. Fair distribution of income

5. PPP per person (control of indicators over resources) is adjusted to reflect the basketry purchasing power parity

6. Achievements in the field of health

7. Gender equality

6. The quality of the environment, people, resources and development, and the impact of their changes on national income and wealth

7. Impact of global concerns on the economy

8. Prosperity, quality of life and economic development of future generations

9. Expenses on pollution, health, floods, car accidents

10. Resources and production capacity of exploited people and ecosystems

11. Impact of economic growth on biodiversity

12. The impact of social costs, health costs on future generations and nation's income.

\section{Blumberg's Global Health Index}

Blumberg's Global Health Index ${ }^{6}$, published by Blumberg's media, measures the state of health of the country. It is important to remember that although this is also included in the calculation, the state of health care is not measured. For various reasons, the latter is more often aimed at treating diseases than health and healthy life. The index analyzes life expectancy, primary mortality risk, high blood pressure, obesity, smoking rates, alcohol consumption, childhood malnutrition, sanitation, and clean water-number of smokers, physical movement, but also child malnutrition, mental health, and vaccinations.

Spain - with its Mediterranean diet and high life expectancy is the healthiest country in the world, according to the blumberg' 2019 Index. This year, five European countries were on the list of the top 10. Meanwhile, the United States took a distance $35^{\text {th }}$ place.

What makes Spain the healthiest country? One of the likely factors is the universal healthcare system. Primary care is generally provided by public suppliers, specialized family doctors, and nurses who offer preventive services for children, women, and elderly patients as well as care for acute and chronic diseases.Another reason may be the Mediterranean diet (Figure 2), which includes olive oil, vegetables, nuts and fruit; moderate amounts of fish, wine and dairy products; and low meat consumption other than fish. Adherence to this heart-healthy diet is associated with longer life and fewer cardiovascular severe events. But just to be sure, some say it's not just about ingredients, it's about a healthy lifestyle. 


\begin{tabular}{|c|c|c|c|c|c|c|}
\hline Rank & Country & $\begin{array}{l}\text { Human Development } \\
\text { Index Value }\end{array}$ & $\begin{array}{l}\text { Life Expectancy } \\
\text { at Birth }\end{array}$ & $\begin{array}{l}\text { Expected Years } \\
\text { of Schooling }\end{array}$ & $\begin{array}{l}\text { Mean Years of } \\
\text { Schooling }\end{array}$ & $\begin{array}{c}\text { Gross National } \\
\text { Income per Capita }\end{array}$ \\
\hline 1 & Norway & 0.954 & 82.3 & 18.1 & 13 & 68,059 \\
\hline 2 & Switzerland & 0.946 & 83.6 & 16.2 & 13.4 & 59,375 \\
\hline 3 & Ireland & 0.942 & 82.1 & 18.8 & 12.5 & 55,660 \\
\hline 4 & Germany & 0.939 & 81.2 & 17.1 & 14.1 & 46,946 \\
\hline 4 & Hong Kong & 0.939 & 84.7 & 16.5 & 12 & 60,221 \\
\hline 6 & Australia & 0.938 & 83.3 & 22.1 & 12.7 & 44,097 \\
\hline 6 & Iceland & 0.938 & 82.9 & 19.2 & 12.5 & 47,566 \\
\hline 8 & Sweden & 0.937 & 82.7 & 18.8 & 12.4 & 47,955 \\
\hline 9 & Singapore & 0.935 & 83.5 & 16.3 & 11.5 & 83,793 \\
\hline 10 & Netherlands & 0.933 & 82.1 & 18 & 12.2 & 50,013 \\
\hline 11 & Denmark & 0.93 & 80.8 & 19.1 & 12.6 & 48,836 \\
\hline 12 & Finland & 0.925 & 81.7 & 19.3 & 12.4 & 41,779 \\
\hline 13 & Canada & 0.922 & 82.3 & 16.1 & 13.3 & 43,602 \\
\hline 14 & New Zealand & 0.921 & 82.1 & 18.8 & 12.7 & 35,108 \\
\hline 15 & United Kingdom & 0.92 & 81.2 & 17.4 & 13 & 39,507 \\
\hline 16 & United States & 0.92 & 78.9 & 16.3 & 13.4 & 56,140 \\
\hline 17 & Belgium & 0.919 & 81.5 & 19.7 & 11.8 & 43,821 \\
\hline 18 & Liechtenstein & 0.917 & 80.5 & 14.7 & 12.5 & 99,732 \\
\hline 19 & Japan & 0.915 & 84.5 & 15.2 & 12.8 & 40,799 \\
\hline 20 & Austria & 0.914 & 81.4 & 16.3 & 12.6 & 46,231 \\
\hline 21 & Luxembourg & 0.909 & 82.1 & 14.2 & 12.2 & 65,543 \\
\hline 22 & Israel & 0.906 & 82.8 & 16 & 13 & 33,650 \\
\hline 22 & Korea & 0.906 & 82.8 & 16.4 & 12.2 & 36,757 \\
\hline 24 & Slovenia & 0.902 & 81.2 & 17.4 & 12.3 & 32,143 \\
\hline 25 & Spain & 0.893 & 83.4 & 17.9 & 9.8 & 35,041 \\
\hline 26 & Czechia & 0.891 & 79.2 & 16.8 & 12.7 & 31,597 \\
\hline 26 & France & 0.891 & 82.5 & 15.5 & 11.4 & 40,511 \\
\hline 28 & Malta & 0.885 & 82.4 & 15.9 & 11.3 & 34,795 \\
\hline 29 & Italy & 0.883 & 83.4 & 16.2 & 10.2 & 36,141 \\
\hline 30 & Estonia & 0.882 & 78.6 & 16.1 & 13 & 30,379 \\
\hline 31 & Cyprus & 0.873 & 80.8 & 14.7 & 12.1 & 33,100 \\
\hline 32 & Greece & 0.872 & 82.1 & 17.3 & 10.5 & 24,909 \\
\hline 32 & Poland & 0.872 & 78.5 & 16.4 & 12.3 & 27,626 \\
\hline 34 & Lithuania & 0.869 & 75.7 & 16.5 & 13 & 29,775 \\
\hline 35 & United Arab Emirates & 0.866 & 77.8 & 13.6 & 11 & 66,912 \\
\hline 36 & Andorra & 0.857 & 81.8 & 13.3 & 10.2 & 48,641 \\
\hline 36 & Saudi Arabia & 0.857 & 75 & 17 & 9.7 & 49,338 \\
\hline 36 & Slovakia & 0.857 & 77.4 & 14.5 & 12.6 & 30,672 \\
\hline 39 & Latvia & 0.854 & 75.2 & 16 & 12.8 & 26,301 \\
\hline 40 & Portugal & 0.85 & 81.9 & 16.3 & 9.2 & 27,935 \\
\hline 41 & Qatar & 0.848 & 80.1 & 12.2 & 9.7 & 110,489 \\
\hline 42 & Chile & 0.847 & 80 & 16.5 & 10.4 & 21,972 \\
\hline 43 & Brunei Darussalam & 0.845 & 75.7 & 14.4 & 9.1 & 76,389 \\
\hline
\end{tabular}

In terms of life expectancy at birth, Spain ranks first in the European Union and third in the world, behind Japan and Switzerland. According to the forecasts of the Institute of Metrics and Health Assessment of the University of Washington, by the year 2040, the average life expectancy in Spain will reach almost 86-years, the highest in the world.

The next nations on the list are Iceland, Japan, Switzer- 

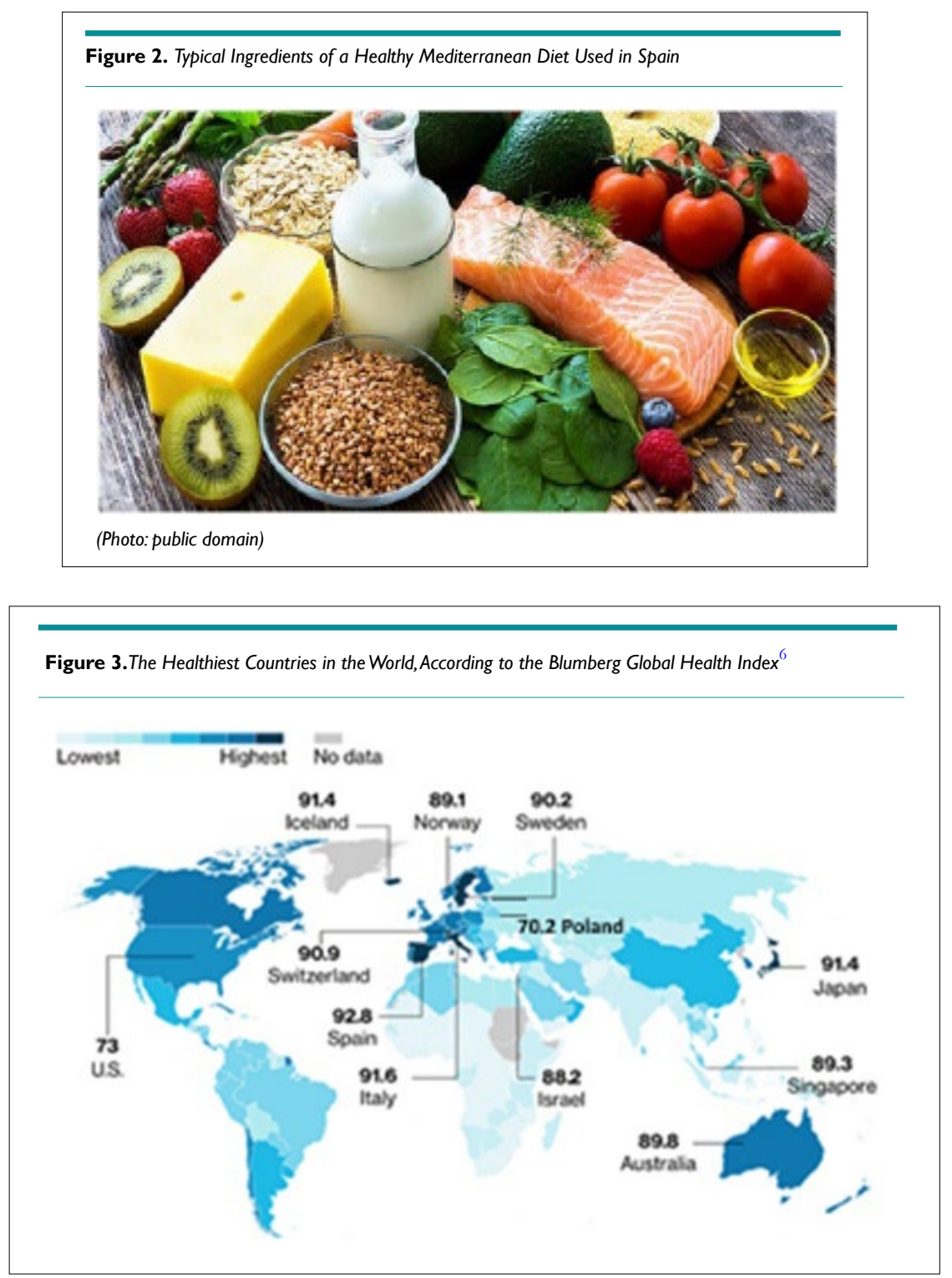

land, and Italy, which in 2019 fell from the highest position. It is worth noting, however, that it is difficult to assess the health of nations accurately, and the results of different indexes differ when they use different methodologies. For example, the Legatum Prosperity Index 2018 stated that Spain took 22 places on the list of the healthiest countries in the world (Singapore was number one).

Interestingly, both indexes agreed that the United States is not a particularly healthy country - both came in $35^{\text {th }}$ place. Why is the United States lagging? One of the evident factors is diet. Almost half of Americans suffer from some chronic illness due to poor diet, including heart disease. What's more, two-thirds of American adults and nearly a third of children are overweight or obese. This overweight is partly related to the prevalence of processed and cheap and unhealthy food in the United States. But perhaps the worst feature of Americans' eating habits is eating huge portions-something that can be seen in the increased size of tableware since the 1960s. As the result of the unhealthy diet in recent years, more Americans are more likely to die from suicide and drug overdose than in car accidents. The Blumberg Global Health Index index illustrates this issue in Figure 3.

\section{HEALTHCARE SERVICE EFFICIENCY INDICATORS |}

Healthcare is maintaining or improving health by preventing, diagnosing, and treating diseases, injuries, diseases, and other physical or mental disorders. Health care includes dentistry, psychology, nursing, medicine, physical therapy, occupational therapy, and many others. Access to healthcare varies between countries, municipalities, and individuals, and is mostly influenced by economic and social factors.

According to the World Health Organization (WHO), a well-functioning healthcare system requires a permanent financing mechanism, a properly trained and adequately paid workforce, well-maintained facilities, and access to reliable information based on which decisions are made. 
Table 2. The European Health Consumer Index in 2018

\begin{tabular}{|c|c|c|}
\hline † Switzerland & 1 & 893 \\
\hline = Netherlands & 2 & 883 \\
\hline 해틀 Norway & 3 & 857 \\
\hline 믈 Denmark & 4 & 855 \\
\hline Belgium & 5 & 849 \\
\hline + Finland & 6 & 839 \\
\hline = Luxembourg & 7 & 809 \\
\hline 플 Sweden & 8 & 800 \\
\hline Eustria & 9 & 799 \\
\hline 믐들 Iceland & 10 & 797 \\
\hline France & 11 & 796 \\
\hline Germany & 12 & 785 \\
\hline - 2 Portugal & 13 & 754 \\
\hline Czech Republic & 14 & 731 \\
\hline Estonia & 15 & 729 \\
\hline Uâa United Kingdom & 16 & 728 \\
\hline
\end{tabular}

\begin{tabular}{|c|c|c|}
\hline Slovakia & 17 & 722 \\
\hline Serbia & 18 & 699 \\
\hline 드 Spain & 19 & 698 \\
\hline I Italy & 20 & 687 \\
\hline Slovenia & 21 & 678 \\
\hline In Ireland & 22 & 669 \\
\hline Montenegro & 23 & 668 \\
\hline$=$ Croatia & 24 & 644 \\
\hline EA North Macedonia & 25 & 638 \\
\hline - Cyprus & 26 & 635 \\
\hline Malta & 27 & 631 \\
\hline Lithuania & 28 & 622 \\
\hline 柱 Greece & 29 & 615 \\
\hline Eatvia & 30 & 605 \\
\hline Bulgaria & 31 & 591 \\
\hline Poland & 32 & 585 \\
\hline = Hungary & 33 & 565 \\
\hline Romania & 34 & 549 \\
\hline Flbania & 35 & 544 \\
\hline
\end{tabular}

Many people see access to healthcare as a fundamental human right. Lack of high-quality healthcare can result in poor quality of life and shorter life expectancy than in countries with stable and accessible healthcare system.

How is the quality of healthcare defined? Several factors determine the level of quality of healthcare in each country and include:

- Care process (preventive measures, safe care, coordinated care, and patient involvement and preferences)

- Access (availability and timeliness)

- Administrative efficiency

- Equality in access

- Healthcare outcomes (population health, health-related mortality, and disease)

- Specific patient health outcomes.

Healthcare outcomes are resulting from specific measures or investments. Healthcare outcomes include acceptable mortality, readmission, and patient experience. The Healthcare Access \& Quality Index (HAQ) evaluates healthcare outcomes on a scale of 0 to 100 , with 100 being the best. Countries with the best healthcare systems in the world have scores from 90 to 96.1. In 2020, France comes first.
In Europe, the most popular is the European Health Consumer Index (EHCI), compares European healthcare systems based on (Table 2):

- Patient rights and information,

- Waiting time for a medical service,

- Treatment results,

- The scope and range of medical services,

- Prevention.

The data is presented as a graphic index (in which table or figure?). The index measures the 'consumer-friendliness' of healthcare systems. He (Who?) does not claim to measure which European country has the best healthcare system but creates specialized indexes for diabetes, cardiac care, HIV, headache, and hepatitis. In 2006, France was the champion, with 768 points per 1000. In the 2015 results, the same result would give $13^{\text {th }}$ position among 35 countries.

\section{THE REVIEW OF THE HEALTHCARE SYSTEMS IN SEVERAL COUNTRIES $^{8}$}

\section{Switzerland}

In 2018, healthcare was the friendliest in this country, which is 


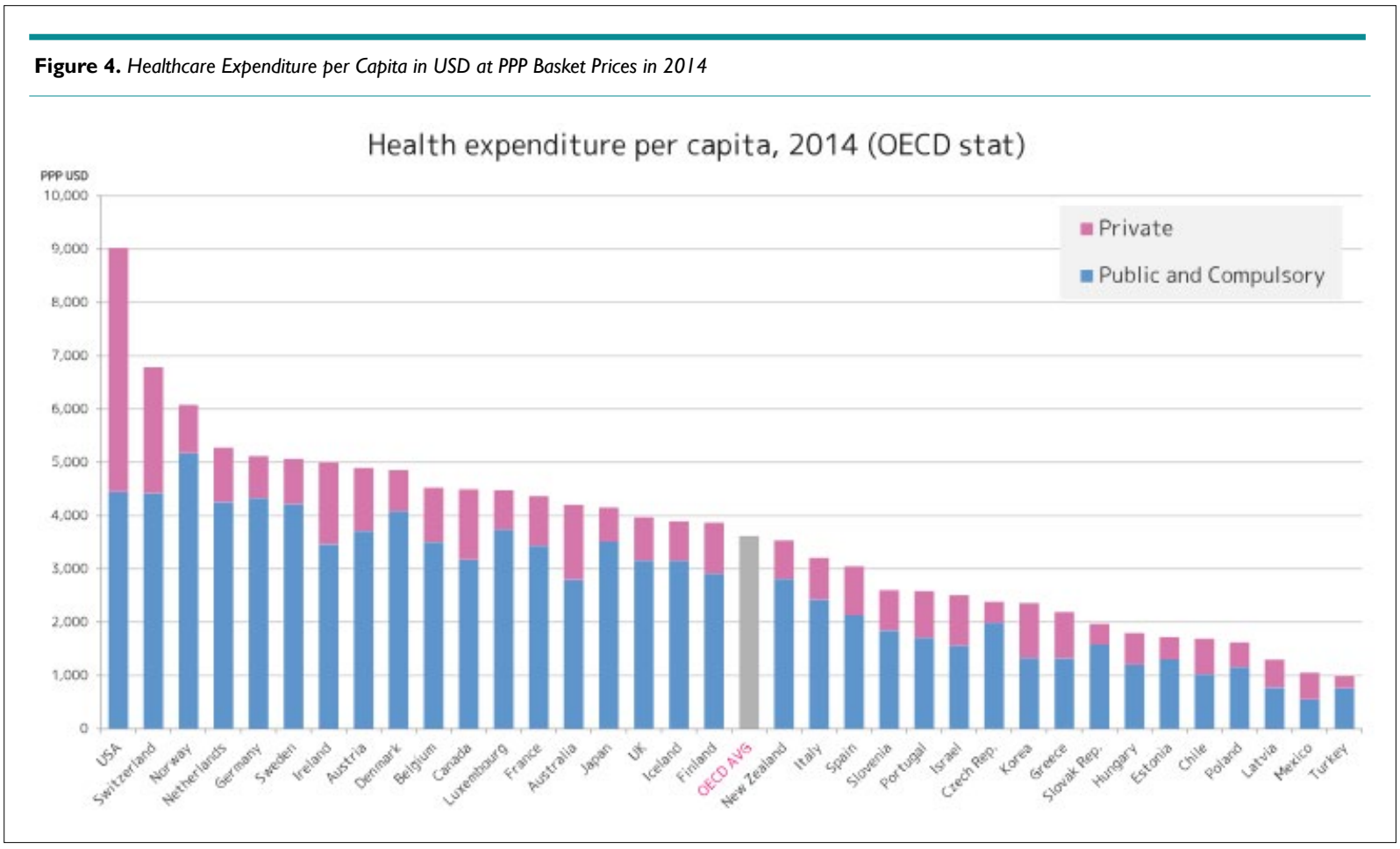

widespread and subject to the Swiss Federal Health Insurance Act. There are no free health services provided by the state. Still, private health insurance is compulsory for everyone residing in Switzerland (within three months of living or being born in the country). Health insurance covers the costs of medical treatment and hospitalization of the insured. The insured, however, covers part of the costs of treatment.

\section{The Netherlands}

The Netherlands has universal healthcare, but the government requires that all adults living or working in the Netherlands have basic insurance. The basic plan costs $100-120 €$ out of pocket. If employed, the employer pays a small percentage of the insurance costs. Children under the age of 18 do not pay for health insurance. The basic plan includes a basic standard of care, such as visits to the general proactitioner (GP) and hospital. Some treatments may have a surplus, for which you have to pay part from your pocket. Many people also decide to obtain a higher level of insurance coverage for an additional fee, which compensates for other treatments not covered by the basic insurance package. To give an overview of some of the costs that can be encountered, here are typical costs for healthcare in the Netherlands:

- Basic monthly insurance plan $100 €$

- One-day hospital stay $146 €$

- Visit the emergency room $256 €$

- Doctor visit during regular business hours $47 €$

- Doctor visit outside regular working hours $92 €$

\section{Denmark}

Healthcare in this country is mostly provided by the self-govern- ments of five regions, with coordination and regulation by the central government. At the same time, 98 municipalities are responsible for nursing homes, home care, and school health services. Some specialized hospital services are centrally managed. The Danish government's healthcare expenditure is around $10.4 \%$ of GDP, of which about $84 \%$ is financed from regional and city taxes redistributed by the central government. Since taxpayers finance the necessary healthcare, personal expenses are minimal and usually involve the co-financing of certain services. These expenses are typically covered by private health insurance. The use of electronic medical records is widespread, and efforts are being made to integrate this data at the regional level.

\section{Sweden}

The Swedish healthcare system is funded mainly by the government, universal for all citizens, and decentralized, although private healthcare also exists. The healthcare system in Sweden is financed primarily from taxes collected by the county and municipal councils. In the country, 21 councils supervise primary and hospital care. Private healthcare is rare in Sweden, and even those private institutions operate under the authority of city councils. City councils regulate rules and establish potential private practices. Although in most countries, care for the elderly or those in need of psychiatric assistance is provided privately, in Sweden, local, publicly funded authorities are responsible for these types of care. The Swedish government is trying to restrict private healthcare companies. The government is taking precautions to eliminate profit-seeking in the social welfare and public health sectors.

\section{Austria}

Austria has one of the best healthcare systems in the world, and access to medical services can be considered exemplary interna- 


\begin{tabular}{|c|c|c|c|c|c|}
\hline State & $\begin{array}{l}\text { Society Health } \\
\text { Blumberga Indeks }\end{array}$ & Lifespan & $\begin{array}{l}\text { Ranking of Healthcare } \\
\text { (EHCl) }\end{array}$ & $\begin{array}{l}\text { Funding as } \\
\% \text { of GNP }\end{array}$ & $\begin{array}{l}\text { Funding PPP Per } \\
\text { Capita in Euro }\end{array}$ \\
\hline Spain & 92.8 & 83.4 & 19 & 6.4 & 1,535 \\
\hline Italy & 91.6 & 83.6 & 20 & 6.6 & $\mathrm{I}, 847$ \\
\hline Switzerland & 90.9 & 83.4 & I & 12.2 & 6,917 \\
\hline Sweden & 90.2 & 82.7 & 8 & 9.2 & 4,272 \\
\hline Norway & 89.1 & 82.3 & 3 & 10.4 & 5,485 \\
\hline France & 86.9 & 82.5 & 11 & 9.5 & 3,193 \\
\hline Austria & 86.3 & 81.4 & 4 & 7.7 & 3,136 \\
\hline Netherlands & 85.9 & 82.1 & 2 & 8.4 & 3,478 \\
\hline U. Kingdom & 84.9 & 81.2 & 16 & 7.7 & 3,874 \\
\hline Portugal & 83.6 & 82.11 & 13 & 9 & 1,684 \\
\hline Germany & 83 & 81 & 12 & 11.4 & $4,7 \mid 4$ \\
\hline Danmark & 82.7 & 80.8 & 4 & 8.6 & 4,217 \\
\hline $\begin{array}{l}\text { Czech } \\
\text { Republik }\end{array}$ & 77.6 & 79.2 & 14 & 5.9 & 978 \\
\hline USA & 73 & 78.9 & Not in Europe & 16.9 & 8,643 \\
\hline Poland & 70.2 & 78.5 & 32 & 4.6 & 510 \\
\hline \multicolumn{6}{|c|}{ Source: the author } \\
\hline
\end{tabular}

tionally. The modernization program has a clear goal: the welfare of citizens. The principle of statutory health insurance combined with co-insurance for children and non-working partners guarantees that $99 \%$ of the entire population will be covered by health insurance. With the introduction of the minimum income system, its beneficiaries are also covered by compulsory social security. In the event of temporary incapacity for work, employees are entitled to sickness benefits that occur in connection with the continued payment of wages by the employer (employers are obliged to continue paying wages for six to twelve weeks). If the illness continues, depending on the employee's insurance history, sickness benefits can range from six months to one year. The minimum level of monthly sickness benefits is $50 \%$ of the individual's previous gross wage. Eight weeks before and eight weeks after the birth of a child, mothers usually receive maternity allowance corresponding to their current income from work.

\section{France}

Insurance for all residents of France is compulsory. The social security system covers $70 \%$ of the cost of treatment. All citizens pay to the state health insurance system which is managed by three central funds.. The rates are regulated by law, and must be charged to the percentage of patient's or employer's income. One of the reasons why the French system is widely cited is that long-term medical problems are $100 \%$ covered by the state. Otherwise, patients will pay a fee for the doctor or dentist and then receive a partial refund.

Further, refunds occur when a person pays for health insurance. All employees are entitled to plans subsidized by the company. That means that healthcare in France is one of the most subsidized and cheapest in the world. The government's insurance program is managed through a French social security office, where $70 \%$ of services cover all everyday healthcare needs, including general practitioners, hospitals, dentists, and pharmacy costs. Services for the elderly who are 65-years of age and older or chronically ill are fully covered. To pay for additional services, such as chiropractors or long-term care in private hospitals, individuals can take out private insurance. They can either pay for it themselves or, in some cases, the employer will pay the extra amount. Residents of France can sign up for a mutuelle, non-profit insurance plan, or private plan for additional protection. Often this private care can fill a gap where people should pay co-costs or want to receive elective treatment. If the employee is employed, he will automatically be covered by a plan in which his company spends at least half of the additional costs.

\section{The Czech Republic}

The Czech Republic has a healthcare system based on the compulsory insurance model, and care for services has been financed from mandatory employment-related insurance plans since 1992. Czech healthcare ranks $13^{\text {th }}$, followed by Sweden and two positions ahead of Great Britain. The Czech healthcare system is characterized by a high degree of decentralization and uses market forces compared to other universal European systems.

The quality of health care also largely depends on the expenditure imposed on it. Figure 4 illustrates healthcare expenditure per capita in USD. 


\section{HEALTHCARE IN DEVELOPING NATIONS}

According to Benyoussef et $\mathrm{al}^{9}$ some developing countries have developed healthcare programmes at the most peripheral level to meet the health and development needs of the deprived populations in the following manners:

- China uses mass education programmes and "barefoot doctors" to deliver primary health services.

- Tanzania has instituted massive rural population re-location efforts to facilitate delivering healthcare and other government-sponsored development service, by subordinating health care per se to the related projects of agriculture, water supply and housing.

- India have encouraged village acceptance of primary health care.

- Iran has a good referral systems at local levels to highly specialized hospitals.

- Cuba has extended coverage to nearly all of its population.

- Niger applyies voluntary workers who help keeping costs at a minimum.

- Sudan has a National Health Programme has.

None of these approaches have reported enough data to be completely evaluated, but each has attained some degree of success in serving deprived populations".

\section{CONCLUSION}

Table 3 characterizes indicator profiles of selected countries in the EU and the USA.

It is striking comparing the healthiest countries in the world such as Spain and Italy which are spending on health services per capita 5-times less than the most developed country in the world the United States, whose habitants stragelling with health. The Americans's health is in the range of post-Soviet Bloc countries such as the Czech Republic and Poland where the spending on health per capita is about 10 times smaller than in the U.S. It is indicating that the healthy life style is the key solution in the effort of improving health of habitants.

From those shown in Table 3, the health characteristics of the countries follow the following observations:

1. The health of society depends to a great extent on lifestyle and climate. While both factors are reasonable, there are fewer sick people and the resulting lower burden on healthcare as evidenced by the following examples:

a. Spain has the healthiest society in Europe (92.8) and health service $19^{\text {th }}$ place in the $19^{\text {th }}$ place, which was visible in its problems during the cross-i-out 2020 pandemic.

b. Italy, as well as Spain, has a healthy society (91.6) in Europe, which is only $20 \%$ in health status, which was visible in its problems during the 2020 pandemic.
2. Countries with a worse climate than the Mediterranean climate, maintain their health due to the excellent efficiency of health care (well-healing), as evidenced by the following examples:

a. Switzerland has a healthy society (90.9), but due to the high mountain climate, it must have efficient healthcare, which is number one in Europe, functioning at a very high cost, as high as $12.2 \%$ of GDP.

b. Norway also has a healthy society (89.1), but due to the northern climate, it must have an efficient health service, which is in third place in Europe, functioning at a very high cost, as high as $10.4 \%$ of GDP.

c. Similar relationships in public health are between France with a pleasant climate and a light diet, and Germany and the Netherlands with a northern climate, and a heavy diet.

d. Similar relationships in public health are between Portugal with a pleasant climate and a light diet, and Germany and Denmark with a northern climate, and a heavy diet.

3. The example of health and quality of the United States healthcare service shows how, despite the high quality of private health care, the health of the society is low (worse than Czechs and similar to Poles) due to the highly unhealthy lifestyle, characterized by fat and large portions, diet and almost immobility of people who are always in cars. Also, 30+\% of people have no health insurance. That is why American healthcare must compensate for lifestyle defects with intensive treatment and expensive medicines. This issue was at the financially painful test during the 2020 pandemic.

4. Knowledge of the best health care systems in the world should be universal knowledge available to all people in the world. On its basis, health care systems in individual countries should be developed and implemented, adjusted to the traditions and financial capabilities of given citizens and the state. It is strange that the WHO does not develop this knowledge and does not motivate its members to improve the health care systems of their inhabitants. As for the United States, its health care system should result from the synthesis of the best solutions in the world to break with its parish character, unworthy of the country with the largest number of the best universities and the largest number of Nobel laureates who can solve almost any challenging problem.

\section{REFERENCES}

1. Maddison A. The World Economy: A Millenial Perspective. France, Paris: OECD Development Centre; 2001: 31.

2. Targowski A. Harnessing the Power of Wisdom. New York, USA: NOVA Science Publishing; 2013: 56.

3. Institute for Innovation in Social Health. The Index of Social Health. Web site. http://iisp.vassar.edu/ish.html. Accessed June 30, 2020. 
4. Investopedia. Genuine Progress Indicator (GPI). Web site https://www.investopedia.com/terms/g/gpi.asp. Accessed June 30, 2020.

5. The United Nations Human Development Programme. 2019 Human Development Index Ranking. Web site. http://hdr.undp. org/en/content/2019-human-development-index-ranking. Accessed June 30, 2020.

6. Miller LJ, Lu W. Economics: These Are the World's Healthiest Nations. Web site. https://www.bloomberg.com/news/articles/2019-02-24/spain-tops-italy-as-world-s-healthiest-nationwhile-u-s-slips. Accessed June 30, 2020.
7. Healthcare defined by WHO. The World Health Organization's ranking of the world's health systems, by Rank Web site. https:// photius.com/rankings/healthranks.html. Accessed June 30, 2020.

8. European Health Consumer Index (EHCI). Web site. https:// healthpowerhouse.com/media/EHCI-2018/EHCI-2018-report. pdf. Accessed June 30, 2020.

9. Benyoussef A, Christian B. Health care in developing countries. Social Science \&o Medicine (1967). 1977; 11(6-7): 399-408. doi: 10.1016/0037-7856(77)90103-2 